Jurnal Keperawatan Silampari

Volume 2, Nomor 1, Desember 2018

e-ISSN : 2581-1975

p-ISSN : 2597-7482

DOI: https://doi.org/10.31539/jks.v2i1.379

\title{
PENGARUH DO'A TERHADAP TEKANAN DARAH PADA PASIEN GAGAL GINJAL KRONIS (GGK) PRE-HEMODIALYSIS
}

\author{
Hilda Nur Afriani ${ }^{1}$, Rohman Azzam ${ }^{2}$, Busrja M. Nur ${ }^{3}$ \\ Program Studi Magister Keperawatan, Universitas Muhammadiyah Jakarta ${ }^{1,2,3}$ \\ hildanurafriani12@yahoo.com ${ }^{1}$
}

\begin{abstract}
ABSTRAK
Tujuan penelitian ini adalah untuk mengetahui pengaruh intervensi do'a terhadap tekanan darah pre-hemodialisis pasien GGK Di ruang hemodialisis Rumah Sakit Islam Jakarta. Metode penelitian menggunakan metode quasi experiment. Hasil penelitian terdapat penurunan tekanan darah pada kelompok intervensi setelahintervensi do'a baik pada tekanan darah sistolik maupun diastolik. Hasil uji t berpasangan sebelum dan sesudah diberikan intervensi do'a pada kelompok intervensi dan kontrol menghasilkan nilai sig <0.05 pada tekanan darah sistolik dan diastolik, artinya terdapat perbedaan sebelum dan setelah diberikan intervensi do'a. Hasil uji t tidak berpasangan antara kelompok intervensi dan kontrol tekanan darah sistolik menghasilkan nilai sig $>0.05$, artinya tidak terdapat perbedaan antara kelompok intervensi dan kontrol sedangkan tekanan darah diastolik menghasilkan nilai sig $<0.05$, artinya terdapat perbedaan antara kelompok intervensi dan kontrol. Simpulan, pemberian intervensi do'a pada prehemodialysis terbukti dapat menurunkan tekanan darah.
\end{abstract}

Kata Kunci : Do’a, Gagal Ginjal Kronis, Tekanan Darah

\section{ABSTRACT}

The purpose of this study was to determine the effect of interventional prayer on prehemodialysis blood pressure in patients with chronic renal failure in the hemodialysis room at the Islamic Hospital in Jakarta. The research method uses quasi experiment method. The results of the study found a decrease in blood pressure in the intervention group after the intervention both in systolic and diastolic blood pressure. Paired t-test results before and after the given intervention in the intervention and control groups produced a sig value $<0.05$ in systolic and diastolic blood pressure, meaning that there were differences before and after the intervention was given. The unpaired $t$-test results between the intervention and control groups of systolic blood pressure produce a sig value $>0.05$, meaning that there is no difference between the intervention and control groups while the diastolic blood pressure produces a sig value <0.05, meaning that there are differences between the intervention and control groups. Conclusion, the administration of prayer interventions in pre-hemodialysis is proven to reduce blood pressure.

Keywords: Prayer, Chronic Kidney Failure, Blood Pressure 


\section{PENDAHULUAN}

Gagal ginjal akut (GGK) ialah penyakit menahun yang menyebabkan ekskresi perifer maupun kegagalan untuk mengkonsentrasikan urine dan penyakit tulang akibat ginjal dimana keadaan ini dapat menjadi parah dan menimbulkan kecacatan (Brunner, Suddart, 2014; Padila, 2012). GGK adalah suatu kondisi yang ditandai dengan hilangnya fungsi ginjal secara bertahap dari waktu ke waktu ditandai dengan GFR $\leq 60$ $\mathrm{ml} / \mathrm{min} / 1.73 \mathrm{~m}^{2}$ (Kozier, 2011).

Data badan kesehatan dunia (WHO) menyebutkan penderita GGK di USA pada tahun 2014 sebanyak 500.000 orang penduduk ditetapkan untuk rutin hemodialysis dan 1.140 orang Amerika therapy peritoneal dialysis, Menurut Kamaludin, Rahayu (2009) jumlah GGK di Indonesia adalah 150.000 juta penduduk dan hemodialysis secara rutin dan terjadwal sebanyak 100.000 ribu orang (Riskesdas, 2013). WHO memperlihatkan yang menderita gagal ginjal baik akut maupun kronik mencapai $50 \%$ sedangkan yang diketahui dan mendapatkan pengobatan hanya $25 \%$ dan $12,5 \%$ yang terobati dengan baik (Riskesdas, 2013).

Menurut Ismail, Hasanuddin, Bahar (2014) jumlah GGK di Indonesia 150.000 juta penduduk dan hemodialysis secara rutin dan terjadwal sebanyak 100.000 ribu orang (Riskesdas, 2013). Peningkatan jumlah pasien gagal ginjal kronik (GGK) yang masih aktif hemodialysis menurut IRR dengan jumlah rata - rata 5.000 orang pada tahun 2007 dan 2008, kemudian meningkat secara perlahan 8.000 orang memilih hemodialysis tahun 2009, pasien hemodialysis rutin dan terjadwal 12.000 ribu orang makin meningkat pada tahun 2010, dan 68.000 ribu orang penduduk Indonesia diharuskan untuk hemodialysis dari tahun 2011 - tahun 2014 (Depkes RI 2013).

Negara Indonesia yang menjalani hemodialysis perkorwil dari urutan tertinggi sampai dengan terendah adalah Jawa Barat sebanyak 5.000 orang, Jawa Timur sebanyak 3.800 orang, Jawa Tengah 2.100 orang, Bali sebanyak 2.100 orang, provinsi DKI (Daerah Khusus Ibukota) Jakarta menempati urutan ke - 5 sebanyak 1800 orang, Sumatera Selatan sebanyak 1.200 orang, Daerah Istimewa Yogyakarta (DIY) sebanyak 900 orang, Sumatera Utara sebanyak 800 orang, Sulawesi sebanyak 300 orang, Kalimantan sebanyak 200 orang, dan Sumatera Barat sebanyak 100 orang (Riskesdas, 2013). Laporan rekap data pasien GGK yang rutin hemodialysis Di RSI Cempaka Putih - Jakarta Pusat menunjukkan bahwa pada 2015 sebanyak 17.647 orang, tahun 2016 sebanyak 18.567 orang dan pada tahun 2017 sebanyak 19.741 orang. Terlihat bahwa jumlah pasien gagal ginjal kronis dari 3 tahun terakhir ini pada tahun 2009 - tahun 2017 meningkat pesat dalam terapi hemodialysis (Rekam Medik RSIJ Cempaka Putih, 2018).

Hemodialisis adalah suatu metode untuk mengeluarkan cairan yang berlebihan dan toksin saat darah pasien bersirkulasi melalui ginjal buatan (dialyzer) (Fransiska. K, 2011). Ginjal membantu mempertahankan tekanan darah (TD) dengan mengeksresikan atau menyimpan natrium dan air. Ketika TD turun, ginjal memulai mekanisme reninangiotensin. Mekanisme renin-angiotensin menstimulasi vasokonstriksi, yang menyebabkan pelepasan hormon aldosteron dari korteks adrenal sehingga meningkatkan reabsorpsi ion natrium dan retensi air. Selain itu, pelepasan hormon antifiuretik (ADH) hipofisis meningkatkan reabsorpsi air oleh ginjal. Hasil bersihnya adalah peningkatan volume darah dan peningkatan CO dan TD (Potter, Perry, 2010).

Komplikasi lainnya yang disebabkan karena terapi hemodialisis (Hirmawaty, 2014) adalah Hipotensi dapat terjadi selama dialisis ketika cairan dikeluarkan, emboli udara merupakan komplikasi yang jarang tetapi dapat saja terjadi jikaudara memasuki sistem vaskuler pasien. Nyeri dada dapat terjadi karena $\mathrm{pCO}_{2}$, menurun bersamaan 
dengan terjadinya sirkulasi darah diluar tubuh, Pruritus dapat terjadi selama terapi dialisis selama produk akhir metabolisme meninggalkan kulit, gangguan keseimbangan dialisis terjadi karena perpindahan cairan serebral dan muncul sebagai serangan kejang. Komplikasi ini kemungkinan terjadi lebih besar jika terdapat gejala uremia yang berat, kram otot yang nyeri terjadi ketika cairan dan elektrolit dan cepat meninggalkan ruang ekstrasel dan mual dan muntah merupakan hal yang sering terjadi.

Kelebihan cairan pre-hemodialysis kemungkinan juga menjadi pemicu tingginya kejadian intradialisis hipertensi. Kelebihan cairan memegang peranan penting dalam kejadian hipertensi pada pasien hemodialysis (Schimdt, 2002 dalam Padila, P, 2012). Observasi selama pengambilan data menunjukkan bahwa sebagian besar pasien mengalami kelebihan cairan pre-hemodialysis. Sebagian besar pasien mengalami peningkatan berat badan 3-5 kg (Rendy, Clevo, 2010).

Perubahan yang akan ditimbulkan pada pasien yang menjalani hemodialisis diantaranya perubahan klinis dan psikologis. Perubahan psikologik yang timbul akibat penyakit ESRD diantaranya terjadi stress fisiologi dan psikologis juga dapat berkontribusi menimbulkan gangguan tekanan darah tinggi. Perubahan klinis diantaranya kelebihan cairan pre hemodialysis sehingga dapat memicu terjadinya darah tinggi (TD) (Schimdt, 2002 dalam Padila, P, 2012).

Tekanan darah (TD) adalah kekuatan yang dikeluarkan oleh darah yang bersirkulasi pada dinding pembuluh darah yang bergerak melalui arteri, arteriol, kapiler, venula, dan vena (Hamid, Azmi, 2009). Pasien GGK pre-hemodialysis di ruang hemodialysis Rumah Sakit Islam Jakarta Cempaka Putih yang disebabkan oleh hipertensi sehingga diperlukan pemantauan (observation) khusus, Selain itu, diperlukan penanganan terhadap peningkatan tekanan darah yang dapat dilakukan dengan intervensi spiritual care yaitu do'a.

Spiritual adalah keyakinan dalam hubungannya dengan Yang Maha Kuasa dan Maha Pencipta, sebagai contoh seseorang yang percaya kepada Allah sebagai Pencipta atau sebagai Maha Kuasa. Spiritualitas mengandung pengertian hubungan manusia dengan Tuhannya dengan menggunakan instrument (medium) sholat, puasa, zakat, haji, doadan sebagainya (Herliawati, dkk, 2014). Doa dan zikir adalah salah satu ritual yang biasa dilakukan oleh umat Islam yang dapat menimbulkan respon relaksasi dan memberikan efek terhadap kesehatan jangka panjang dan perasaan bahagia. Terapi doa dan dzikir juga merupakan bagian dari meditasi transcendental yang dapat menghambat efek stres dengan menurunkan kadar kortisol (Suharyanto, Madjid. 2012).

Dalam mengatasi tekanan darah tinggi terdapat beberapa penelitian untuk mengatasinya diantaranya terapi alternative dengan do'a. Metode intervensi do'a ini akan mengubah fisiologis di otak saat berdoa dan memusatkan fikiran. Dengan Do'a ini mengakibatkan perubahan positif terjadi di hipotalamus - bagian otak yang mengatur fisiologi tubuh melepaskan hormon endorphin yang ikut menurunkan tekanan darah, menurunkan ketegangan otot, menurunkan denyut jantung dan meningkatkan kapasitas paru - paru untuk membawa oksigen ke seluruh tubuh (Smeltzer, S.C, Bare, B.G. 2008). Adapun kegiatan relaksasi dapat dilaksanakan dengan prosedur empat langkah yang melibatkan: (1) menemukan suasana lingkungan yang tenang; (2) mengendorkan otototot tubuh secara sadar; (3) selama sepuluh sampai dua puluh menit memusatkan diri pada perangkat mental; (4) menerima dengan sikap yang pasif terhadap pikiranpikiranyang sedang bergolak (Suratih, K, Suranah \& Riyanto, 2014).

Penderita gagal ginjal kronik harus melakukan terapi hemodialisa untuk memperpanjang usia harapan hidup. Kegiatan ini akan berlangsung terus menerus 
sepanjang hidupnya (Smeltzer, Bare, 2008). Oleh karena itu, kebutuhan pasien pada stadium lanjut suatu penyakit tidak hanya pemenuhan/pengobatan gejala fisik, namun juga pentingnya dukungan terhadap kebutuhan psikologis, sosial dan spiritual yang dilakukan dengan pendekatan interdisiplin yang dikenal sebagai perawatan paliatif (Dhina, 2015). Perawatan paliatif ini dapat menggunakan intervensi dengan psikologis (psychological intervention) berupa relaksasi spiritual melalui doa (Dhina, 2015).

Do'a juga merupakan prosedur yang senantiasa dilakukan sebelum tindakan hemodialysis dimulai saat pasien berada di Ruang Hemodialysis Rumah Sakit Islam Jakarta, namun hingga saat ini belum pernah dilakukan riset secara khusus untuk melihat bagaimana pengaruh do'a terhadap tekanan darah pasien GGK prehemodialysis. Penelitian ini bertujuan untuk menganalisis do'a terhadap tekanan darah pre-hemodialysis pasien GGK di ruang hemodialysis Rumah Sakit Islam Jakarta Cempaka Putih. Mengingat fungsi ginjal yang rusak sangat sulit untuk dilakukan pengembalian, maka tujuan dari penatalaksanaan klien gagal ginjal kronik adalah untuk mengoptimalkan fungsi ginjal yang ada dan mempertahankan keseimbangan secara maksimal untuk memperpanjang harapan hidup klien. Sebagai penyakit yang kompleks, gagalginjal kronik membutuhkan penatalaksanaan terpadu dan serius,sehingga akan meminimalisir komplikasidan meningkatkan harapan hidup klien.

Hasil penelitian Herliawati. Maryatun, S. Herawati, D. (2014) menyatakan implementasi psikoreligus kepada pasien gagal ginjal kronik, dengan cara mempertahankan intensitas pelaksanaan ibadah, meningkatkan pemahaman dan penghayatan keagamaan, terbukti signifikan dapat mengatasi gangguan fisik-psikissosial-spiritual untuk menyikapi berbagai permasalahan kehidupan yang dihadapi dan pasien terlihat jauh dari kata keputusasaan dalam menjalani terapi dialisis.

Selaras dengan hasil penelitian Ema (2016) sebelum dilakukan psychoreligius intervention dengan terapi relaksasi spiritual dzikir didapatkan dari 12 orang responden terdapat 58\% (7 orang) responden mengalami kualitas hidup kurang, itu terlihat dari pasien mayoritas berusia diatas 45 tahun sehingga pasien cenderung mengalami berbagai komplikasi yang memperberat fungsi ginjal sangat besar dibanding dengan yang berusia dibawah 40 tahun, pasien juga sudah lama mengalami hemodialisa. Sedangkan setelah dilakukan intervensi terdapat peningkatan sekitar $42 \%$ kualitas hidup pasien kategori cukup terlihat fisik, psikologi, dan mendapat dukungan keluarga sehingga terjadi peningkatan kualitas hidup antara psychological intervention dengan terapi relaksasi spiritual dzikir terhadap kualitas hidup pada penderita gagal ginjal kronik yang menjalani terapi hemodialisa.

Penderita gagal ginjal kronik (GGK) juga membutuhkan terapi pengganti kerja ginjal yaitu dengan dialisis. Dialisis yang lama menimbulkan keputusasaan sebagai akibat rendahnya spiritual pasien. Terapi spiritual bimbingan dengan intervensi doa merupakan salah satu upaya untuk menurunkan angka keputusasaan. Tujuan penelitian ini adalah untuk mengetahui efektifitas pengaruh intervensi do'a terhadap tekanan darah pada pasien dengan gagal ginjal kronis (ggk) pre - hemodialy.

\section{METODE PENELITIAN}

Penelitian ini menggunakan metode quasi experiment. Quasy Experimental Design adalah penelitian yang dilakukan dengan memberikan treatment untuk variabel penelitian, kemudian baru mengukur hasilnya (Sari, Mekar, Amelia, Artanti, \& Nerisa, 2007). Dengan menggunakan metode Quasy Experimental Design ini dapat 
mempermudah peneliti dalam membagi kelompok sample menjadi kelompok intervensi (intervention group) dan kelompok control (control group).

Dengan pendekatan pretest-posttest with control group design. Rancangan Quasi Experimental minimal memenuhi satu dari tiga syarat rancangan true experiment yaitu sampel diambil secara acak, ada kelompok kontrol dan ada intervensi. Rancangan pretest-posttest control group design dilakukan dengan menilai sebelum dan setelah perlakuan pada kelompok kontrol dan kelompok perlakuan.

Jumlah responden pada pasien GGK pre-hemodialysis di ruang hemodialysis Rumah Sakit Islam Jakarta Cempaka Putih adalah 32 orang. 16 orang responden pada intervention group dan 16 orang pada control group yang memenuhi kriteria inklusi.Pengambilan sampeldalam penelitian ini purposive sampling.

\section{Instrumen Penelitian}

Instrumen data dalam penelitian ini adalah tensimeter digital, lembar observasi tekanan darah responden GGK Pre-hemodialysis dan kuisioner. Dalam kuisioner yang akan digunakan berisi tentang data demografi responden berupa nama responden (dalam bentuk initial), umur responden, gender, jenjang pendidikan dan lama hemodialysis. Sedangkan lembar observasi adalah kertas kerja yang akan digunakan oleh penelitian untuk mendokumentasikan hasil pengukuran tekanan darah yang dilakukan baik PreIntervention maupun Post-Intervention.

\section{Pengumpulan data}

Peneliti akan mengobservasi yaitu mengukur tekanan darah responden menggunakan tensimeter digital merk Omron yang telah siap pakai. Hasil pengukuran dicatat dalam lembar observasi yang terdapat pada meja pasien. Selain itu digunakan juga standar operasional prosedur (SOP) bimbingan do'a yang dipersiapkan oleh peneliti untuk digunakan sebagai alat bantu dalam melakukan intervensi do'a kepada responden (Notoatmodjo, S. (2012). Dalam SOP bimbingan do'a dan pengukuran tekanan darah agar disesuaikan yaitu dilakukan selama 5 hari per-individu. Dalam 1x shift dilakukan pengukuran tekanan darah pada 3 orang responden . Itu berarti dalam $2 x$ shift maka dapat dilakukan pengukuran tekanan darah sebanyak 6 orang terhadap intervention group dan control group. Intervensi do'a dikerjakan bersama-sama dan pengukuran tekanan darah akan dilakukan per-individu terhadap responden yang memenuhi kriteria inklusi.

\section{HASIL PENELITIAN}

\section{Analisis Univariat}

Karakteristik pasien berdasarkan data kategorik pada penelitian ini dan dianalisis menggunakan distribusi frekuensi, sebagaimana disajikan dalam table berikut:

Tabel. 1

Distribusi Frekuensi Karakteristik Responden Hemodialisis

\begin{tabular}{|c|c|c|c|c|}
\hline \multirow{2}{*}{ Karakteristik } & \multicolumn{4}{|l|}{ Kelompok } \\
\hline & Intervensi & $\%$ & Kontrol & $\%$ \\
\hline $\begin{array}{l}\text { Jenis Kelamin } \\
\text { 1. Laki-laki } \\
\text { 2. Perempuan }\end{array}$ & $\begin{array}{l}6 \\
10\end{array}$ & $\begin{array}{l}37.5 \\
62.5\end{array}$ & $\begin{array}{l}7 \\
9\end{array}$ & $\begin{array}{l}43.8 \\
56.3\end{array}$ \\
\hline
\end{tabular}




\begin{tabular}{rllll}
\hline Lamanya HD & 5 & 31.3 & 3 & 18.8 \\
$1 . \quad<12$ Bulan & 11 & 68.8 & 13 & 81.3 \\
2. > 12 Bulan & & & & \\
\hline $\begin{array}{l}\text { Pendidikan } \\
\text { 1. SD }\end{array}$ & 3 & 18.8 & 1 & 6.3 \\
2. SMP & 2 & 12.5 & 1 & 6.3 \\
3. SMA & 10 & 62.5 & 8 & 50.0 \\
4. PT & 1 & 6.3 & 6 & 37.5 \\
\hline
\end{tabular}

Berdasarkan tabel 1 bahwa jenis kelamin terbanyak dalam kelompok intervensi yaitu perempuan sejumlah 10 orang dan sisanya laki-laki sejumlah 6 orang dengan persentase secara berturut-turut yaitu $62.5 \%$ dan $37.5 \%$. sedangkan pada kelompok kontrol jenis kelamin terbanyak yaitu perempuan sejumlah 9 orang dan 7 orang laki-laki dengan persentase secara berturut-turut yaitu $56.3 \%$ dan $43.8 \%$. Hal ini menunjukkan bahwa responden terbanyak dalam penelitian ini adalah Perempuan.

Berdasarkan tabel 1 bahwa lamanya HD terbanyak dalam kelompok intervensi yaitu $>12$ bulan sejumlah 11 orang dan sisanya $<12$ bulan sejumlah 5 orang dengan persentase secara berturut-turut yaitu $68.8 \%$ dan $31.3 \%$. Sedangkan pada kelompok kontrol lamanya HD terbanyak yaitu > 12 bulan sejumlah 13 orang dan 3 orang < 12 bulan dengan persentase secara berturut-turut yaitu $81.3 \%$ dan $18.8 \%$. Hal ini menunjukkan bahwa responden terbanyak dalam penelitian ini adalah responden hemodialysis yang menjalani HD > 12 bulan.

Berdasarkan tabel 1 bahwa tingkat pendidikan terbanyak dalam kelompok intervensi yaitu SMA sejumlah 10 orang dengan persentase $62.5 \%$. sedangkan pada kelompok kontrol tingkat pendidikan sejumlah 8 orang dengan presentasi $50.0 \%$. Hal ini menunjukkan bahwa responden terbanyak dalam penelitian ini adalah responden dengan tingkat pendidikan SMA.

\section{Usia Responden Hemodialisis}

Karakteristik usia merupakan data numerik dan dianalisis menggunakan sentral tendensi untuk mendapatkan nilai mean, median, minimum dan maximum, standar deviasi, serta 95\% CI. Hasil analisis disajikan dalam bentuk table berikut.

Tabel. 2

Analisis Kesetaraan Usia pada Responden GGK Pre-Hemodialysis $(\mathrm{n}=32)$

\begin{tabular}{lccccc}
\hline Variabel & Mean & Median & SD & Min-Maks & $95 \%$ CI \\
\hline Usia & & & & & \\
Kelompok Intervensi & 51.31 & 52.50 & 7.454 & $40-70$ & $47.34-55.28$ \\
Kelompok Kontrol & 54.13 & 54.00 & 9.437 & $40-70$ & $49.10-59.15$ \\
\hline
\end{tabular}

Berdasarkan tabel 2 diatas diperoleh data rata-rata umur responden pada kelompok intervensi adalah 51.31 tahun dengan standar deviasi 7.454. Usia termuda 40 tahun sedangkan usia yang tertua adalah 70 tahun. Dari hasil estimasi interval dapat disimpulkan pada 95\% CI diyakini bahwa rata-rata usia responden pada kelompok intervensi adalah antara 47.34 sampai dengan 55.28 tahun. Rata-rata umur responden pada kelompok kontrol adalah 54 tahun dengan standar deviasi 9.437. Usia termuda adalah 40 tahun sedangkan usia tertua adalah 70 tahun. Dari hasil estimasi interval dapat 
disimpulkan pada 95\% CI diyakini bahwa rata-rata umur responden pada kelompok kontrol adalah antara 49.10 sampai dengan 59.15 tahun.

\section{Analisis Bivariat}

Pada penelitian ini, analisis yang digunakan oleh peneliti adalah uji T dependen dengan hasil sebagai berikut:

Tabel. 3

Analisis Perubahan Tekanan Darah Sebelum dan Setelah Intervensi Do'a Pre-Hemodialysis

\begin{tabular}{|c|c|c|c|c|c|c|c|}
\hline \multirow[b]{2}{*}{ Variabel } & \multirow{2}{*}{$\begin{array}{l}\text { Jenis } \\
\text { Kelompok }\end{array}$} & \multirow{2}{*}{$\begin{array}{l}\text { Kategori } \\
\text { Tekanan } \\
\text { Darah }\end{array}$} & \multicolumn{2}{|l|}{ Mean } & \multirow{2}{*}{$\begin{array}{l}\text { Mean } \\
\text { Selisih }\end{array}$} & \multirow{2}{*}{$\begin{array}{l}\text { Selisih } \\
\text { SD }\end{array}$} & \multirow[b]{2}{*}{ P Value } \\
\hline & & & Sebelum & Setelah & & & \\
\hline \multirow{4}{*}{$\begin{array}{l}\text { Tekanan } \\
\text { Darah }\end{array}$} & & Sistole & 149.75 & 143.75 & 6.00 & 3.01 & \\
\hline & Intervensı & Diastole & 99.38 & 91.50 & 7.87 & 4.22 & $\begin{array}{l}0.000 \\
0.000\end{array}$ \\
\hline & Kontrol & Sistole & 146.63 & 145.38 & 1.25 & 0.62 & \\
\hline & & Diastole & 88.25 & 85.63 & 2.62 & 1.39 & 0.080 \\
\hline
\end{tabular}

Hasil analisis kondisi tekanan darah setelah mendapatkan intervensi do'a pada kelompok intervensi terjadi penurunan tekanan darah dan pada kelompok kontrol kondisi tekanan darah tidak menurun secara signifikan hasil analisa rata-rata menunjukkan bahwa kondisi kodisi tekanan darah pada responden hemodialysis yang mendapatkan intervensi do'a menurun secara bermakna sebesar 6.00 untuk sistol sedangkan untuk diastole 7.87 dengan $\mathrm{p}$ value $<0.05$. Sedangkan pada kelompok control yang tidak mendapatkan intervensi do'a tidak terjadi perubahan secara bermakna. Perubahan yang terjadi hanya sebesar 1.25 untuk sistol dan untuk diastole 2.62 dengan $\mathrm{p}$ value $>0.05$. Berdasarkan data diatas dapat disimpulkan bahwa pada nilai alpha $\geq 5 \%$ terjadi perubahan bermakna kondisi tekanan darah sebelum dan setelah diberikan intervensi do'a pada kelompok intervensi.

\section{PEMBAHASAN}

\section{Analisis Univariat}

Penelitian ini menunjukan paling banyak pasien GGK pre-hemodialysis di ruang hemodialysis berjenis kelamin perempuan yaitu sebanyak 18 orang $(56,3 \%)$ dengan rata-rata usia 53 tahun yang memang sudah memasuki masa menopause. Hasil penelitian persentase tertinggi pada kelompok intervensi pada kriteria $>=40$ tahun ialah 93.8\% sebanyak 15 responden dan nilai persentase tertinggi pada kelompok kontrol adalah $87.5 \%$ sebanyak 14 responden. Selaras dengan teori yang dikemukakan oleh Hamid, Azmi (2009) yang menyatakan bahwa wanita lebih banyak yang menderita GGK dibandingkan pria, hal tersebut dikarenakan sosio demografi dan adanya kecenderungan pola hidup yang kurang baik dimana sebagian wanita terkadang sering melewatkan atau melupakan waktu minum, dan sekalinya minum lebih banyak konsumsi minuman yang siap saji seperti es teh gelas, coca cola dan minuman yang bergas yang lama kelamaan bila dikonsumsi terus-menerus dapat menyebabkan gagal ginjal. 
Selaras dengan teori menurut Padila, P (2012) yang menyatakan gagal ginjal terjadi ketika ginjal tidak mampu mengangkut sampah metabolik tubuh atau melakukan fungsi regulernya. Suatu bahan yang biasanya di eliminasi di urin menumpuk dalam cairan tubuh akibat gangguan ekskresi renal dan menyebabkan gangguan fungsi endokrin dan metabolik, cairan, elektrolit serta asam-basa.

Hasil penelitian ini juga diperkuat oleh penelitian walton. J, (2002) dimana klien yang menjalani hemodialisa berdasarkan distribusi usia didapatkan usia 36-50 tahun pada kelompok intervensi sejumlah 5 klien (50\%) sedangkan usia 36-50 tahun pada kelompok kontrol sejumlah 6 klien $(60 \%)$. Semakin bertambahnya usia fungsi ginjal juga semakin menurun, dimana setelah usia 40 tahun akan menyebabkan terjadinya penurunan laju filtrasi glomerulus secara progresif hingga umur 70 tahun yaitu kurang lebih 50 dari normalnya. Klien yang berada pada usia semakin tua maka akan berpeluang mengalami penyakit salah satunya End Stage Renal Disease (Hamid , Azmi, 2009).

Penelitian ini menunjukan paling banyak pasien ggk pre-hemodialysis diruang hemodialysis dari 32 pasien paling banyak pasien dengan tingkat pendidikan SMA/STM. Tingkat pendidikan ternyata mempengaruhi risiko seseorang terhadap hipertensi. Semakin rendah tingkat pendidikan, semakin besar kemungkinan seseorang mengalami hipertensi dikarenakan pola makan yang salah seperti terlalu banyak konsumsi makan gorengan, jeroan, dan konsumsi tinggi garam (Padila, P, 2012).

Hasil penelitian ini sejalan dengan penelitian yang dilakukan oleh Hanum, dkk (2015) dengan judul pengaruh pendidikan kesehatan secara individual tentang pembatasan asupan cairan terhadap pengetahuan pembatasan cairan dan IDWG klien hemodialisa. Dimana responden dengan tingkat pendidikan rendah berjumlah $24(80 \%)$ sedangkan responden dengan tingkat pendidikan tinggi berjumlah 6 (20\%). Secara umum seseorang yang memiliki tingkat pendidikan tinggi akan mempunyai pengetahuan luas dibandingkan dengan seseorang yang tingkat pendidikannya lebih rendah. Keyakinan biasanya diperoleh secara turun temurun dan tanpa adanya pembuktian terlebih dahulu, keyakinan ini dapat mempengaruhi pengetahuan seseorang baik keyakinan yang sifatnya positif maupun negatif (Notoadmojo, 2012).

Gambaran responden berdasarkan lama hemodialisa memperlihatkan dari 16 pasien pada kelompok intervensi paling banyak pasien lama hemodialisa kurang dari 5 tahun, yaitu sebanyak 12 orang $(75,0 \%)$ dan pada kelompok kontrol paling banyak pasien lama hemodialisa kurang dari 5 tahun, yaitu sebanyak 12 orang $(75,0 \%)$. gambaran responden berdasarkan lama hemodialisa memperlihatkan dari 16 pasien pada kelompok intervensi paling banyak pasien lama hemodialisa kurang dari 5 tahun, yaitu sebanyak 12 orang $(75,0 \%)$ dan pada kelompok kontrol paling banyak pasien lama hemodialisa kurang dari 5 tahun, yaitu sebanyak 12 orang $(75,0 \%)$.

Selaras dengan teori Brunner, Suddath, (2014) pasien CKD yang mengalami gagal ginjal kronik akan menjalani hemodialisa dalam jangka panjang, dengan Frekuensi tindakan HD bervariasi tergantung banyaknya fungsi ginjal yang tersisa, rata-rata penderita menjalani tiga kali dalam seminggu, sedangkan lama pelaksanaan hemodialisa paling sedikit tiga sampai empat jam tiap sekali tindakan terapi. Masalah lain yang harus dihadapi pasien adalah seperti masalah finansial, kesulitan dalam mempertahankan pekerjaan, dorongan seksual yang hilang, depresi dan ketakutan terhadap kematian. Gaya hidup yang terencana berhubungan dengan terapi hemodialisa (misalnya pelaksanaan terapi hemodialisa 2-3 kali seminggu selama 3-4 jam) dan 
pembatasan asupan cairan sering menghilangkan semangat hidup pasien, untuk itu diperlukan intervensi penguat psikologi pasien.

\section{Analisis Bivariat}

Hasil analisa rata-rata menunjukkan bahwa kondisi kodisi tekanan darah pada responden hemodialysis yang mendapatkan intervensi do'a menurun secara bermakna sebesar 6.00 untuk sistol sedangkan untuk diastole 7.87 dengan $\mathrm{p}$ value $<0.05$. sedangkan pada kelompok kontrol yang tidak mendapatkan intervensi do'a tidak terjadi perubahan secara bermakna. Perubahan yang terjadi hanya sebesar 1.25 untuk sistol dan untuk diastole 2.62 dengan p value $>0.05$. berdasarkan data diatas dapat disimpulkan bahwa pada nilai alpha $\geq 5 \%$ terjadi perubahan bermakna kondisi tekanan darah sebelum dan setelah diberikan intervensi do'a pada kelompok intervensi.Hasil penelitian menyimpulkan bahwa terdapat perbedaan signifikan tekanan darah sistolik antara pre dan post intervensi pada kelompok intervensi, dan terdapat perbedaan signifikan tekanan darah diastolik antara pre dan post intervensi pada kelompok intervensi.

Hasil penelitian menujukan bahwa do'a dapat berpengaruh terhadap tekanan darah Pasien GGK Pre-Hemodialysis di ruang Hemodialysis Rumah Sakit Islam Jakarta Cempaka Putih. Do'a adalah memohon sesuatu yang bermanfaat bagi orang, baik mendatangkan manfaat maupun menghindarkan ancaman bahaya atau menghilangkannya, serta meminta dipenuhinya kebutuhan - kebutuhan kepada Allah dengan aksi nyata (Greenberg, J.S, 2012). Oleh karena itu dengan diberikan do'a pasien merasa lebih baik, sehingga tekanan darah pun menjadi turun. Hasil penelitian menyimpulkan tidak terdapat perbedaan signifikan tekanan darah sistolik antara kelompok intervensi dan kelompok kontrol. Sedangkan untuk rata-rata tekanan diastolik hasil penelitin menyimpulkan terdapat perbedaan signifikan rata-rata tekanan darah diastolik antara kelompok intervensi dan kontrol.

Do'a dapat menurunkan tekanan darah secara perlahan karena memanjatkan permintaan kesembuhan dan kekuatan kepada Allah SWT melalui ayat suci Al-Qur'an sehingga memberikan kesehatan fisik dengan meriksasi syaraf otak dan tubuh yang diatur oleh hypothalamus melalui fourth ventricle menuju ke spinal cord melalui syaraf parasymphatetic yang berfungsi memperlambat detak jantung melalui sympathetic preganglionic fiber melewati sympathetic postganglionic fiber dan cardiac nerve menuju ke ventrikel kanan yang merupakan ruang jantung yang berfungsi dalam memompa darah terdeoksigenasi ke paru - paru. Dalam keadaan rileks, kerja jantung menurun saat aorta mengedarkan darah kaya oksigen ke dalam sel - sel jaringan tubuh sehingga menimbulkan tekanan darah menurun secara perlahan (Suharyanto, Madjid, 2012).

Selaras dengan penelitian yang dilakukan Elizabet, (2014) dan Razieh Mirzaeian, et al, (2017) yang menjelaskan bahwa terjadi penurunan yang signifikan pemberian terapi doa terhadap tekanan darah pada pasien yang menderita gagal ginjal kronik. Proses adaptasi yang sulit dibentuk dari perspektif ini dan perlu bagi individu untuk memobilisasi sumber daya untuk menangani masalah dan semua perubahan yang berasal dari perawatan. Dalam konteks ini, doa adalah sumber daya yang mampu mendorong kembalinya agama atau spiritual, membawa harapan, dan membantu mereka yang menggunakannya untuk merasa lebih kuat dan lebih aman untuk menghadapi penyakit, perawatan, dan seluruh konteks yang mereka hadapi. Selain itu, dapat dianggap sebagai praktik pelengkap untuk pengobatan . 
Penelitian ini juga selaras dengan penelitian yang dilakukan oleh Ali Akbar Walton, J (2002) yang menunjukkan terjadi penurunan tekanan darah yang signifikan sebelum dan sesudah diberikan intervensi terhadap tekanan darah dan tingkat kesadaran. Hasil penelitian ini menunjukkan pengaruh ayat-ayat Al-Qur'an dalam mengurangi tanda-tanda vital dan meningkatkan tingkat kesadaran. Mempertimbangkan metode yang mudah dan bebas biaya ini, metode ini dapat digunakan untuk memberikan langkah efektif dalam meningkatkan kondisi pasien yang dirawat di bangsal khusus dan untuk pasien lain yang menderita ketegangan dan ketidakstabilan tanda-tanda vital karena berbagai penyebab.

Suratih, K. Suranah, \& Riyanto (2014) mempelajari efek Al-Qur'an pada tandatanda vital dan tekanan oksigen arteri pada pasien yang dianestesi yang dirawat di ruang bangsal ICU dan menemukan bahwa suara Al-Qur'an menyebabkan tanda-tanda vital pasien menjadi stabil dan meningkatkan tekanan oksigen asteri. Selain itu, Mir Baqer (2011) dengan membandingkan efek musik dan ayat-ayat Alquran pada tingkat kecemasan dan tanda-tanda vital pasien sebelum operasi perut menemukan bahwa baik musik dan ayat-ayat Alquran memiliki efek positif pada tekanan darah, denyut nadi dan respirasi, seperti serta tingkat kecemasan pada pasien.

Dalam praktik keperawatan, suara Al-Qur'an sebagai intervensi yang efektif dapat menjadi bagian dari rencana perawatan pasien, berfungsi sebagai alat perawatan noninvasif untuk meningkatkan status hemodinamik dan indikator fisiologis pasien. Selain itu, melakukan tindakan ini oleh perawat sangat penting untuk membuka jalan untuk mencapai kemandirian profesional. Di sisi lain, menyediakan ayat-ayat Al-Qur'an adalah teknik murah yang tidak memerlukan sumber daya manusia yang signifikan. Oleh karena itu, suara Al-Qur'an dapat memainkan peran sebagai intervensi keperawatan dalam perawatan pasien yang dirawat di ICU. Itu juga menunjukkan bahwa dalam penelitian ini, suara Alquran bisa efektif dalam meningkatkan indeks fisiologis (tekanan darah, denyut jantung dan pernapasan), dan tingkat kesadaran pada pasien, dan karena perubahan penting dari indeks ini pada pasien yang dirawat. ICU menempatkan pasien dalam kondisi kritis, oleh karena itu, direkomendasikan bahwa suara Alquran digunakan bersama dengan terapi lain di unit perawatan intensif (Ali Akbar Nasril et al, 2017).

Spiritualitas adalah sumber daya yang terkait dengan harapan dan mampu memberikan dukungan dalam mengatasi penyakit yang menyebabkan perubahan dan penderitaan pada manusia, dan itu harus didorong oleh para profesional dalam perawatan pasien yang menjalani hemodialisis (Elizabet, 2014). Selama wawancara, banyak yang menyatakan bahwa intervensi memberikan momen refleksi pada kehidupan mereka, masa depan, dan kemungkinan memulihkan kondisi sehat mereka. Hemodialisis mengubah dinamika kehidupan dan menuntut adaptasi terhadap rutinitas dan perilaku baru, yang mungkin memerlukan pengorbanan dan lupus dan dapat menyebabkan kesulitan, kelelahan, dan stress. Mungkin itulah sebabnya mengapa banyak orang mendeskripsikan spiritualitas sebagai kekuatan untuk menggerakkan hidup mereka dan mendorong harapan untuk mengatasi situasi sulit yang timbul dari CKD dan hemodialisis. Oleh karena itu, dimasukkannya praktik spiritual dalam perawatan kesehatan dapat memperluas sumber daya yang tersedia untuk memberikan kenyamanan, menawarkan manfaat pasien dari interaksi antara tubuh dan roh. Dengan demikian, doa dapat dianggap sebagai kemungkinan perawatan spiritual, mampu memberikan efek positif pada pengobatan orang dengan CKD (Elizabet, 2014). 
Kesehatan seseorang tergantung pada keseimbangan faktor fisik, psikologi, sosiologi, budaya dan spiritual. Spiritualitas yang positif akan mempengaruhi dan meningkatkan kesehatan serta sebagai kegiatan pencegahan penyakit (Potter, Perry, 2010). Sedangkan menurut penelitian Suratih dkk (2014) tentang pengaruh bimbingan spiritual Islami terhadap kualitas hidup klien yang menjalani terapi hemodialisa di RSUD Kabupaten Semarang terdapat perbedaan kualitas hidup klien yang tidak dan yang diberikan bimbingan spiritual islami. Oleh karena itu pemberian spiritual dapat meningkatkan kualitas hidup karena merasakan perasaan yang nyaman dan tenang. Hal ini sejalan dengan penjelasan Suratih, dkk (2014) bahwa perawatan secara spiritual dapat membuat suasana klien menjadi lebih nyaman dan tenang.

Oleh karena itu menurut peneliti dengan pendekatan spiritual doa akan mampu membuat seorang klien menjadi lebih tenang secara psikologis, optimis serta mampu beradaptasi terhadap terapi dan kondisi yang sedang dijalaninya. Hal lain diungkapkan oleh Suratih, dkk (2014) bahwa sebuah kegiatan spiritual akan memiliki dampak yang positif termasuk untuk meningkatkan kemampuan beradaptasi disaat seseorang sedang sakit. Kesehatan seseorang tergantung pada keseimbangan faktor fisik, psikologis, spiritual serta proses penyembuhan sering terjadi dengan adanya kepercayaan atau spiritual sehingga kepercayaan dan harapan individu akan mempengaruhi kesejahtraan fisik dan psikologis seseorang (Potter, Perry, 2010). Sejalan dengan teori Lubis yang menyatakan bahwa agama atau spiritual mempunyai makna yang penting bagi manusia karena iman dapat berfungsi sebagai penghibur dikala duka, menjadi sumber kekuatan batin pada saat menghadapi kesulitan, pemicu semangat dan harapan, pemberi sarana aman karena merasa selalu berada dalam lindungan-Nya, penghalau rasa takut karena merasa selalu dalam pengawasan-Nya, tegar menghadapi masalah karena selalu ada petunjuk melalui firman-firman-Nya, menjaga kemuliaan moral dan berprilaku baik terhadap lingkungan sebagaimana dicontohkan para rasul-Nya (Suratih, dkk, 2014).

\section{SIMPULAN}

Berdasarkan hasil penelitian diperoleh kesimpulan sebagai berikut:

Pada penelitian ini diketahui bahwa karakteristik responden lebih banyak pada kelompok usia dewasa akhir, sedangkan jenis kelamin lebih banyak perempuan, lamanya hemodialysis $>12$ bulan dan pendidikan responden lebih banyak SMA.

Terbukti adanya perbedaan yang signifikan rata-rata tekanan darah pada pengukuran pre-intervensi dan post-intervensi pada kelompok intervensi. Tidak ada perbedaan yang signifikan rata-rata tekanan darah pada pengukuran pre-intervensi dan post-intervensi pada kelompok kontrol.

Terbukti adanya perbedaan yang signifikan rata-rata tekanan darah pada pengukuran pre-intervensi dan post-intervensi pada kelompok intervensi dan kelompok kontrol.

Pemberian intervensi do'a pada pre-hemodialysis terbukti dapat menurunkan tekanan darah.

\section{SARAN}

Kepada peneliti selanjutnya dalam proses pemberian intervensi do'a, peneliti melakukan intervensi do'a tersebut dengan waktu yang telah ditentukan dan sesuai dengan jadwal yang telah ditetapkan dengan waktu penelitian lebih panjang, karena persepsi setiap orang berbeda, dalam hal ini do'a yang didengarkan pada pasien dan laksanakan intervensi ini dengan mengajak ahli agama. 
Untuk pengembangan penelitian diharapkan dilakukan penelitian lebih lanjut dengan menambah variabel-variabel penelitian dengan cara mengkombinasikan intervensi doa dengan edukasi dan atau dengan pendekatan yang lain dan media yang berbeda yang dapat meningkatkan keyakinan pasien dalam menjalani terapinya sehingga dalam menjalani terapi hemodialisa pasien jauh dari keputusasaan.

\section{DAFTAR PUSTAKA}

Brunner. \& Suddarth's. (2014). Textbook of Medical Surgical Nursing. Lippincott: Williams Wilkins

Depkes RI. (2013). Pedoman Pengendalian Penyakit Jantung dan Pembuluh Darah. URL : Dirjen P3L

Dhina, W. (2015). Peningkatan Kualitas Hidup pada Penderita Gagal Ginjal Kronik yang Menjalani Terapi Hemodialisa Melalui Psychological Intervention. Jurnal ilmu kesehatan, 3(2)

Ema. (2016). Peningkatan Kualitas Hidup pada Penderita Gagal Ginjal Kronik yang Menjalani Terapi Hemodialisa melalui Psychological Intervention di Unit Hemodialisa Rs Royal Prima Medan. Jurnal Keperawatan dan Kebidanan

Elizabeth J, Corwin. (2014). Buku Saku Patofisiologi Edisi 3. Jakarta: EGC

Fransiska. K. (2011). 24 Penyebab Ginjal Rusak. Jakarta: Penerbit Cerdas Sehat

Greenberg, J.S. (2012). Comprehensive Stress Management. Eight edition

Hamid , A. (2009). Predictor of Survival among and Stage Renal Failure Patients Undergoing Dialysis Treatment in Pahang From 2000 To 2004. Jurnal of Comunication Health, 15

Herliawati, M, S. Herawati, D. (2014). Pengaruh Pendekatan Spiritual terhadap Tingkat Kesepian pada Lanjut Usia di Panti Sosial Tresna Werdha Warga Tamakelurahan Timbangan Kecamatan Indralaya Utara. Jurnal Keperawatan Sriwijaya, 1(1). ISSN No 23555459

Kamaluddin, R. \& Rahayu, E. (2009). Analisis Faktor-Faktor yang Mempengaruhi Kepatuhan Asupan Cairan pada Klien Gagal Ginjal Kronik dengan Hemodialisis di RSUD Prof. Dr.Margono Soekarjo Purwokerto. Jurnal Keperawatan Soedirman (The Soedirman Journal of Nursing), 4(1)

Kozier, B. ERB, G. Berman, A. Snyder, J.S. (2011). Buku Ajar Fundamental Keperawatan, Konsep, Proses, \& Praktik. (7 ed ). Vol 2. Jakarta: EGC

Notoatmodjo, S. (2012). Metodologi Penelitian Kesehatan. Edisi Revisi. Jakarta: Rineka Cipta

Ns. Padila. (2012). Buku Ajar Keperawatan Medikal Bedah. Yogyakarta: Nuha Medika

Potter, A.P. \& Perry, G.A. (2010). Fundamental of Nursing. Concepts, Process and Practice. $\left(7^{\text {th }}\right.$ ed). Imprint of ElsivierInc: Mosby

Riskesdas. (2013). Badan Penelitian dan Pengembangan Kesehatan Kementerian Kesehatan RI. Jakarta

Rekam Medik RSIJ Cempaka Putih (2018)

Rendy, C. M. (2010). Keperawatan Medikal Bedah. Jakarta: EGC

Suharyanto \& Madjid. 2012. Asuhan Keperawatan pada Klien dengan Gangguan Sistem Perkemihan; Copy Editor: Agung Wijaya, A.md-Jakarta: TIM

Smeltzer, S.C. \& Bare, B.G. (2008). Brunner and Suddarth's Teksbook of Medikal Surgical Nursing. Philadelphia Williams dan Wilkins 
Suratih, K. Suranah. R. (2014). Pengaruh Bimbingan Spiritual Islami terhadap Kualitas Hidup Klien Hemodialisis di RSUD Kabupaten Semarang. Prosiding Konferensi Nasional II PPNI Jawa Tengah 2014

Walton, J. (2002). Finding a Balance: A Grounded Theory Study of Spirituality in Hemodialysis Patients/Commentary. Nephrology Nursing Journal, 29(5) ProQuest Nursing \& Allied Health Source pg. 447 